\title{
EFEKTIVITAS PENDEKATAN RATIONAL EMOTIVE BEHAVIOR THERAPY (REBT) DALAM MENINGKATKAN PENYESUAIAN SOSIAL ANAK ASUH DI PANTI ASUHAN WIRA LISNA PADANG
}

\author{
Imalatul Khaira \\ Universitas Negeri Padang
}

Firman

Universitas Negeri Padang

\author{
Neviyarni S \\ Universitas Negeri Padang
}

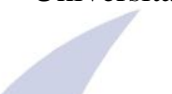

\begin{abstract}
Abstrak
Penyesuaian sosial sebagai proses penyesuaian berlangsung secara berkelanjutan. Dalam hidup mereka, seseorang akan dihadapkan pada dua realitas yaitu diri dan lingkungannya. Anak asuh yang melanggar peraturan panti asuhan, tidak bertanggung jawab, dan tidak dapat berkomunikasi dengan baik adalah indikasi penyesuaian sosial yang rendah. REBT melihat bahwa ketidakmampuan individu dalam hubungan interpersonal dihasilkan dari pemikiran irasional. Salah satu upaya yang dilakukan untuk memperbaiki penyesuaian sosial adalah dengan melakukan pendekatan $R E B T$. Penelitian ini bertujuan untuk mengetahui efektifitas pendekatan REBT dalam meningkatkan asuhan sosial asuh. Penelitian ini merupakan Desain Pretest-Posttest One Group. Dengan teknik Simple Random Sampling. Kelas terdiri dari 10 siswa perlakuan diberikan dalam 6 pertemuan. Instrumen itu adalah model skala Likert. Data dianalisis dengan menggunakan Wilcoxon Signed Ranks Test yang dibantu dengan SPSS versi 20.00. Hasilnya menunjukkan bahwa pada umumnya kelompok pengaturan REBT efektif dalam meningkatkan penyesuaian sosial anak asuh di panti asuhan Wira Lisna Padang. Sementara itu, secara khusus, ada perbedaan skor rata-rata antara penyesuaian sosial anak asuh sebelum dan sesudah melakukan pengaturan
\end{abstract} REBT.

Kata Kunci: Pendekatan REBT, Penyesuaian Sosial

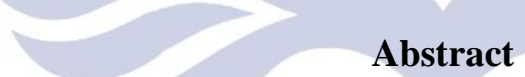

The social adjustment as a process of adjustment to takes place in a sustainable. In their life, a person will be confronted with two realities that is self and their surroundings. Foster children that break the rules of orphanage, irresponsible, and unable to communicate well is indicative of the low social adjustment. $R E B T$ looked that the inability of individuals in interpersonal relationship resulting from irrational thinking. One of the efforts made to improve social adjustment is by doing REBT approach. This research was aimed at revealing the effectiveness of $R E B T$ approach in improving foster care social adjustment. This research is a One Group Pretest-Posttest Design. By using Simple Random Sampling technique. The class consisted of 10 students the treatment was given in 6 meetings. The instrument was a scale model of Likert. Data were analyzed by using Wilcoxon Signed Ranks Test assisted with SPSS versi 20.00. The result indicates that, in general, REBT approach Setting Group was effective in improving the social adjustment of foster children in orphanages Wira Lisna Padang. Meanwhile, in particular, there was a significant differences in the average scores between the social adjustment foster children before and after doing REBT approach Setting Group.

Keywords: $R E B T$ approach, social adjustment

\section{PENDAHULUAN}

Masa remaja merupakan tahap perkembangan membawa individu menuju kematangan fisik, emosional, sosial, dan mental. Masa remaja sebagai masa penentu kesuksesan untuk tahap-tahap perkembangan selanjutnya yang terjadi pada usia 12 sampai 22 tahun. Tugas perkembangan remaja yang berkaitan dengan hubungan sosial menurut Havighurst (dalam Yusuf, 2006) yaitu: (1) mencapai hubungan sosial yang lebih matang dengan teman-teman sebaya, baik dengan teman sejenis maupun lawan jenis, (2) mencapai peran sosial sebagai pria atau wanita artinya dapat menerima peranan masing-masing sesuai dengan ketentuan yang berlaku di masyarakat, dan 
(3) mencapai tingkah laku yang bertanggung jawab secara sosial yang berlaku di dalam masyarakat.

Kemampuan remaja dalam memenuhi tugas-tugas perkembangan sosial akan mengantarkan individu dalam kemampuan menyesuaikan diri di lingkungan sosial. Schneiders (1964) menjelaskan, penyesuaian sosial merupakan cara yang dilakukan individu dalam menyelaraskan kebutuhan internal dengan kebutuhan eksternal yang tercermin dalam kemampuan menjalin relasi dengan orang lain, berpartisipasi dalam pergaulan, menunjukkan minat, dan menunjukkan kepuasan dalam beraktivitas.

Surya (2003) menjelaskan bentuk mekanisme penyesuaian sosial dikelompokkan dalam kategori sebagai berikut: (a) penyesuaian sosial yang normal (well adjustment), seperti; tidak menunjukkan adanya ketegangan emosional, memiliki pertimbangan rasional dan pengarahan diri, dan menghargai pengalamannya, (b) penyesuaian diri yang salah (maladjustment), seperti; bertingkah laku yang salah, emosional, sikap yang tidak realistis, dan agresif, dan (c) penyesuaian yang patologis (pathologic adjustment).

Schneiders (dalam Ali dan Asrori, 2004) menjelaskan setidaknya ada lima faktor yang dapat mempengaruhi proses penyesuaian sosial individu, yaitu:(1) kondisi fisik, meliputi: hereditas dan konstitusi fisik, sistem utama tubuh, dan kesehatan fisik, (2) kepribadian, meliputi: kemauan dan kemampuan untuk berubah (modifiability), pengaturan diri (self-regulation), realisasi diri (selfrealization), dan intelegensi, (3) pendidikan, meliputi: belajar, pengalaman, latihan, dan determinasi diri, (4) lingkungan, meliputi: lingkungan keluarga, lingkungan sekolah, dan lingkungan masyarakat, dan (5) agama dan budaya.

Keluarga merupakan bagian terpenting dari jaringan sosial sekaligus sebagai lingkungan pertama remaja untuk memperoleh pengalaman sosial dini, yang berperan dalam menentukan hubungan sosial dimasa depan dan juga perilakunya terhadap orang lain. Kepuasan psikis yang diperoleh remaja dalam keluarga sangat menentukan bagaimana ia akan bereaksi terhadap lingkungan. Keluarga bagi anak asuh adalah orangtua asuh dan anakanak asuh lainnya. Oleh karena itu, pengasuh dan pembina panti yang menjadi orangtua pengganti bagi anak asuh perlu memberikan perhatian khusus terhadap kemampuan penyesuaian sosial di usia remaja yang akan memfokuskan kepada kehidupan sosial.

Berdasarkan data dari Dinas Sosial Kota Padang pada tahun 2014 telah berdiri 24 panti asuhan di kota Padang, salah satunya adalah Panti Asuhan Wira Lisna yang berlokasi di Kelurahan Mata Air Kecamatan Padang Selatan. Panti asuhan ini didirikan pada bulan Januari Tahun 1994 atas kerjasama Bapak Muktar Aziz dengan
Yayasan Wira Lisna. Panti ini bertujuan untuk mendidik anak-anak yang dititipkan oleh orangtua mereka. Jumlah anak asuh sebanyak 38 orang. Anak asuh pada umumnya adalah anak yatim piatu, anak duafa dan mualaf. Menurut Putra dan Rahma (2013), panti asuhan memberikan sumbangsih yang besar untuk mendidik, membina anakanak terlantar, dan telah melakukan berbagai usaha bersama masyarakat untuk memberikan pelayanan pada anak asuh.

Panti Asuhan Wira Lisna memberlakukan pemberian poin pelanggaran seperti di sekolah. Pelanggaran ringan diberi sanksi seperti dinasehati dan dipanggil keluarga yang bersangkutan. Sedangkan pelanggaran berat diberi sanksi seperti dipulangkan kepada keluarganya. Sejauh ini yang melakukan pelanggaran berat dan dipulangkan kepada keluarga adalah anak asuh yang berusia remaja. Berdasarkan data yang peneliti peroleh dari data harian anak asuh yang melakukan pelanggaran, terlihat secara umum bahwa permasalahan yang sering terjadi adalah menyangkut penyesuaian sosial, seperti cara komunikasi, bergaul, dan sikap menghargai. Berikut ini beberapa perwakilan data anak asuh yang sering melanggar peraturan di panti dan mendapatkan sanksi berupa surat perjanjian serta beberapa yang telah dikeluarkan dari panti dari Tahun 2014-2015.

Tabel 1. Data Catatan Harian Anak Asuh Panti Asuhan Wira Lisna

\begin{tabular}{|c|c|c|c|}
\hline No & Inisial & Bentuk Pelanggaran & Keterangan \\
\hline 1 & $\mathrm{DF}$ & $\begin{array}{l}\text { 1. Melawan dengan } \\
\text { berkata kasar kepada } \\
\text { pengasuh. } \\
\text { 2. Berkata kotor dengan } \\
\text { sengaja di depan } \\
\text { pengasuh/pengurus } \\
\text { panti. }\end{array}$ & $\begin{array}{l}\text { Sudah } \\
\text { dikeluarkan }\end{array}$ \\
\hline 2 & AN & $\begin{array}{l}\text { 1. Bepergian tidak minta } \\
\text { izin kepada } \\
\text { pengasuh/pengurus. } \\
\text { 2. Berbohong kepada } \\
\text { pengasuh/pengurus. }\end{array}$ & $\begin{array}{l}\text { Diberi surat } \\
\text { perjanjian }\end{array}$ \\
\hline 3 & DP & $\begin{array}{l}\text { 1. Keluar malam tanpa } \\
\text { izin pengasuh. } \\
\text { 2. Melakukan } \\
\text { penggeroyokan kepada } \\
\text { anak asuh laki-laki di } \\
\text { asrama putra. }\end{array}$ & $\begin{array}{l}\text { Diberi surat } \\
\text { perjanjian }\end{array}$ \\
\hline 4 & HP & $\begin{array}{l}\text { 1. Berkomunikasi dengan } \\
\text { bahasa kotor kepada } \\
\text { pengasuh. } \\
\text { 2. Bepergian tidak minta } \\
\text { izin kepada pengasuh. }\end{array}$ & $\begin{array}{l}\text { Diberi surat } \\
\text { perjanjian }\end{array}$ \\
\hline
\end{tabular}

Sumber: Catatan Harian Panti Asuhan Wira Lisna

Kemudian peneliti juga melakukan wawancara dengan pengasuh pada tanggal 4 Mei 2015 pukul 17.00 WIB, terkait dengan permasalahan yang sering terjadi pada anak asuh usia remaja yaitu mengenai penyesuaian sosial. Dari 
hasil wawancara, pengasuh mengungkapkan bahwa anak asuh yang berusia remaja baik laki-laki maupun perempuan masih kurang bertanggung jawab dalam menyelesaikan tugas dan kewajibannya, sering bertengkar, merasa rendah diri, merasa iri terhadap kehidupan teman yang berada di luar panti, masih ada yang belum bisa menerima keadaan diri sendiri, dan masih rendahnya sikap saling menghargai terutama kepada pengasuh.

Selanjutnya peneliti juga mewawancarai beberapa anak asuh yang berusia remaja terkait dengan penyesuaian sosial. Dari hasil wawancara, anak asuh mengungkapkan bahwa ia sering dimarahi oleh pengasuh karena temanteman di panti, anak asuh lebih memilih untuk diam dan menyimpan masalah yang dihadapinya daripada bercerita kepada pengasuh maupun kepada teman karena merasa bahwa dirinya tidak akan didengarkan oleh orang lain, masih sering membenci diri sendiri dan keluarga karena tinggal di panti asuhan, malas mengerjakan tanggung jawab di panti seperti piket karena jarang dimarahi oleh pengasuh, tidak mempunyai jadwal kegiatan harian. Terkadang juga merasa tidak perlu mendengarkan teman yang lain berkeluh kesah karena menganggap bahwa ia tidak pernah mengeluh pada orang lain. Hal yang membuat anak asuh sering melanggar peraturan panti sebagian besar adalah karena anak asuh berpikir bahwa mereka merasa terbuang dan anak asuh tidak menginginkan kehidupan yang jauh dari keluarga.

Shaffer (dalam Hartati dan Respati, 2012) menjelaskan, anak-anak yang diasuh dalam panti asuhan mengalami ketidakmatangan dalam perkembangan sosial. Pada umumnya anak-anak ini mengalami kesulitan dalam proses sosialisasi khususnya dalam memulai hubungan dan membina hubungan yang dekat dan akrab. Selanjutnya Hartini (dalam Hartati dan Respati, 2012) menjelaskan bahwa adanya hambatan perkembangan psikologis dan sosial anak panti asuhan, dimana anak asuh lebih kaku dalam hubungan sosial dengan orang lain, perkembangan, dan 1 penyesuaian sosial kurang memuaskan.

Pelayanan bimbingan dan konseling dapat diberikan sebagai bantuan untuk meningkatkan penyesuaian sosial anak asuh. Pelayanan konseling tidak terbatas pada lingkungan pendidikan sekolah, melainkan juga dalam setting luar sekolah dan kemasyarakatan. Hartono dan Soedarmadji (2012) menjelaskan, konseling merupakan pelayanan publik (public service) yang diabdikan untuk memfasilitasi perkembangan individu sebagai anggota masyarakat, agar terhindar dari hambatan atau kendala, sehingga diperoleh kebahagiaan hidup. Wilayah kekhususan konseling mencakup pendidikan, perkawinan, karier, rehabilitasi, kesehatan mental, dan traumatis.
Fenomena kedua yang peneliti temukan di Panti Asuhan Wira Lisna adalah di panti tersebut tidak memiliki konselor, namun di panti asuhan pernah dilaksanakan pelayanan konseling oleh mahasiswa Universitas Negeri Padang yang melakukan Praktik Lapangan Bimbingan dan Konseling (PLBK). Untuk menanggulangi masalah penyesuaian sosial anak asuh, telah dilakukan dengan menggunakan layanan bimbingan kelompok. Akan tetapi layanan bimbingan kelompok yang dilaksanakan belum optimal, dikarenakan pemberian layanan mengenai penyesuaian sosial masih kurang efektif dan masih monoton sehingga anggota kelompok tidak mendapatkan pemahaman tentang urgensi dari isi layanan tersebut.

Berdasarkan fenomena penyesuaian sosial anak asuh yang ditemukan, maka perlu dientaskan karena dapat menghambat pengembangan potensi sosialnya. Pelaksanaan layanan konseling dapat dioptimalkan dan diaktifkan dengan menggunakan pendekatan yang dapat mendukung dalam pelaksanaan layanan, sehingga permasalahan yang dialami anak asuh dapat tersentuh dengan pendekatan yang diberikan. Oleh sebab itu, peneliti tertarik untuk mengembangkan pendekatan Rational Emotive Behavior Therapy (selanjutnya disebut dengan $R E B T$ ).

Konseling REBT bertujuan untuk memperbaiki dan mengubah sikap, persepsi, cara berpikir, keyakinan serta pandangan klien yang irasional menjadi rasional, sehingga ia dapat mengembangkan diri dan mencapai realisasi diri yang optimal. Di samping itu, REBT bertujuan menghilangkan gangguan emosional seperti: benci, takut, rasa bersalah, cemas, was-was, marah sebagai akibat berpikir yang irasional, dan melatih serta mendidik klien agar dapat menghadapi kenyataan hidup secara rasional dan membangkitkan kepercayaan diri, nilai-nilai, dan kemampuan diri.

Salah satu yang menjadi latar belakang peneliti menggunakan REBT adalah untuk membantu meningkatkan kemampuan interpersonal remaja dalam hubungannya dengan penyesuaian sosial. Sebagaimana yang dijelaskan oleh Latipun (2011) bahwa klien yang sangat cocok untuk REBT adalah klien yang mengalami kecemasan pada tingkat moderat, gangguan neurotik, gangguan karakter, problem psikosomatik, gangguan makan, ketidakmampuan dalam hal hubungan interpersonal, problem perkawinan, keterampilan dalam pengasuhan, dan disfungsi seksual.

Ellis dan Dryden (2003:1) menjelaskan REBT sebagai berikut ini.

Rational Emotive Behavior Therapy (REBT) is an approach to counselling that can be placed firmly in the cognitive-behavioral tradition of psychoterapy, meaning that it particularly focuses on the way that we 
think and behave, in its attempt to understand our emotional responses.

REBT adalah sebuah pendekatan untuk konseling yang dapat ditempatkan dalam tradisi kognitif-behavior psikoterapi, yang berarti bahwa terfokus pada cara kita berpikir dan berperilaku, dalam upaya untuk memahami respon emosi. Agar pelaksanaan pendekatan REBT tersebut teruji kualitasnya, maka perlu diuji keefektivitasan pendekatan REBT dalam meningkatkan penyesuaian sosial anak asuh di Panti Asuhan Wira Lisna Padang yang berusia remaja.

\section{METODOLOGI}

Penelitian ini merupakan penelitian kuantitatif dengan metode penelitian eksperimen menggunakan desain true experimental. Bentuk true experimental yang digunakan dalam penelitian ini adalah pretest posttest control group.

Bentuk rancangan penelitian eksperimen yang akan dilakukan:

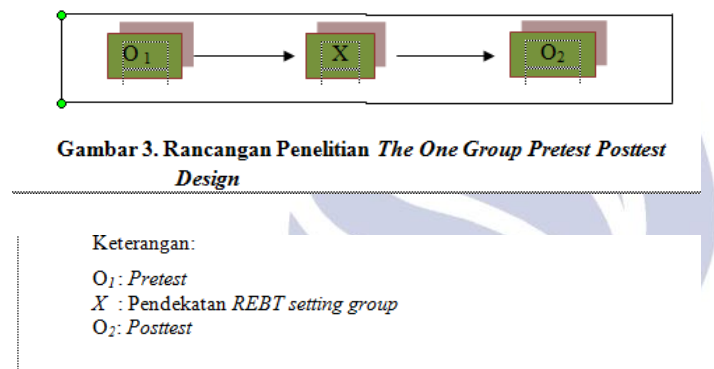

Penelitian ini menggunakan metode kuantitatif. Jenis penelitian ini adalah One Group Pretest-Posttest Design. Populasi penelitian adalah anak asuh usia remaja di Panti Asuhan Wira Lisna Padang yng berjumlah 20 orang dan sampel 10 orang dipilih menggunakan teknik Simple Random Sampling. Instrumen penelitian yang digunakan dengan model Skala Likert. Uji validitas instrumen penelitian melalui uji validitas isi oleh tiga orang ahli dan juga dilakukan menggunakan Spearman's Rho dan uji reliabilitas menggunakan rumus Alpha Cronbach. Selanjutnya, data yang diperoleh dianalisis dengan menggunakan uji Wilcoxon Signed Ranks Test dengan bantuan SPSS versi 20.00 .

\section{HASIL PENELITIAN}

A. Deskripsi Data

Berikut deskripsi data penyesuaian sosial anak asuh

\begin{tabular}{|c|c|c|c|c|c|c|}
\hline \multirow{3}{*}{ No } & \multicolumn{6}{|c|}{ Penyesuaian Sosial } \\
\hline & \multicolumn{3}{|c|}{ Pretest } & \multicolumn{3}{|c|}{ Posttest } \\
\hline & \begin{tabular}{c|} 
Inisial \\
Responden
\end{tabular} & Skor & Kategori & \begin{tabular}{c|c} 
Inisial \\
Responden
\end{tabular} & Skor & Kategori \\
\hline 1 & $\mathrm{AR}$ & 104 & $\mathrm{~KB}$ & $\mathrm{AR}$ & 132 & CB \\
\hline 2 & $\mathrm{NH}$ & 111 & $\mathrm{CB}$ & $\mathrm{NH}$ & 169 & B \\
\hline 3 & UH & 112 & CB & UH & 167 & B \\
\hline 4 & NY & 103 & $\mathrm{~KB}$ & NY & 161 & B \\
\hline 5 & ER & 104 & KB & ER & 160 & B \\
\hline 6 & MP & 118 & CB & MP & 180 & SB \\
\hline 7 & $\mathrm{SE}$ & 102 & $\mathrm{~KB}$ & $\mathrm{SE}$ & 163 & B \\
\hline 8 & Vo & 103 & $\mathrm{~KB}$ & VO & 168 & B \\
\hline 9 & SF & 101 & KB & SF & 170 & B \\
\hline 10 & $\mathrm{AZ}$ & 102 & $\mathrm{~KB}$ & $\mathrm{AZ}$ & 138 & CB \\
\hline & Jumlah & 1060 & & & 1608 & \\
\hline & Rata-rata & 106 & $\begin{array}{c}\text { Kurang } \\
\text { Baik }\end{array}$ & & 160,8 & Baik \\
\hline
\end{tabular}

kelompok eksperimen

1. Hasil Pretest dan Posttest Penyesuaian Sosial Anak Asuh di Panti Asuhan Wira Lisna

Skor penyesuaian sosial anak asuh di panti asuhan masing-masing anak asuh pada posttest mengalami peningkatan dari skor pretest. Pada saat pretest, kondisi penyesuaian sosial anak asuh pada umumnya kurang baik (maladjustment), kemudian setelah diberikan perlakuan dan dilakukan posttest terlihat semua skor meningkat. Kondisi penyesuaian sosial yang rendah setelah diberikan perlakuan dialami oleh AR, dan yang terbaik dialami oleh MP. Namun secara umum semua subjek penelitian mengalami peningkatan skor.

2. Perbedaan Hasil Pretest dan Posttest Kondisi Penyesuaian Sosial Anak Asuh

Perbedaan frekuensi kondisi penyesuaian sosial untuk masing-masing kategori dari hasil pretest dan posttest dapat dilihat pada tabel berikut.

Tabel8. Distribusi Frekuensi Penyesuaian Sosial Anak Asuh Pretest-Posttest

\begin{tabular}{|c|c|c|c|c|c|}
\hline \multirow{2}{*}{ Interval } & \multirow{2}{*}{ Kategori } & \multicolumn{2}{|c|}{ Pretest } & \multicolumn{2}{c|}{ Posttest } \\
\cline { 3 - 6 } & & $\mathrm{F}$ & $\%$ & $\mathrm{~F}$ & $\%$ \\
\hline$\geq 177$ & Sangat Baik & 0 & 0 & 1 & 10 \\
\hline $143-176$ & Baik & 0 & 0 & 7 & 70 \\
\hline $109-142$ & Cukup Baik & 3 & 30 & 2 & 20 \\
\hline $75-108$ & Kurang Baik & 7 & 70 & 0 & 0 \\
\hline$\leq 74$ & Tidak Baik & 0 & 0 & 0 & 0 \\
\hline \multicolumn{2}{|c|}{ Jumlah } & 10 & 100 & 10 & 100 \\
\hline
\end{tabular}

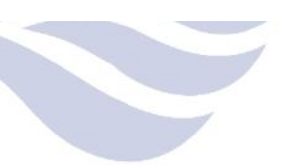

Selanjutnya Untuk melihat kondisi penyesuaian sosial anak asuh pada masing-masing anak asuh dari hasil pretest dan posttest dapat dilihat pada gambar berikut ini.

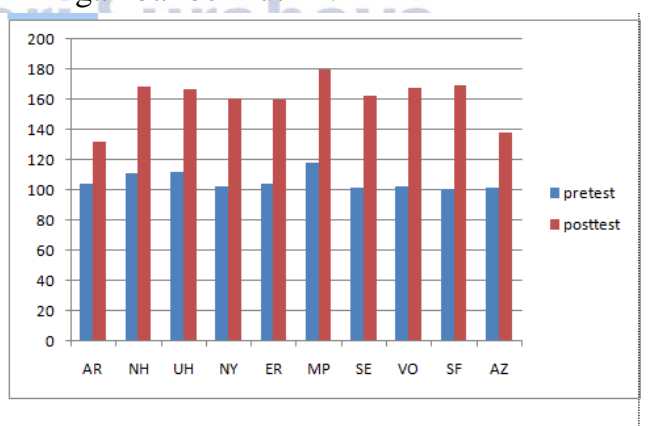

Gambar 5. Hasil Pretest dan Posttest Penyesuaian Sosial Anak Asuh

\section{B. Pengujian Hipotesis}

Pengujian hipotesis pada penelitian ini menggunakan analisis statistik non-parametrik dengan uji Wilcoxon menggunakan SPSS versi 20.00. Uji Wilcoxon digunakan 
untuk menganalisis hasil-hasil pengamatan yang berpasangan dari dua data sebelum dan setelah perlakuan. Analisis ini digunakan apabila peneliti ingin melihat ada atau tidaknya perbedaan kondisi subjek penelitian antara sebelum dan setelah diberikan perlakuan (Siegel, 1997).

Hipotesis yang diajukan dalam penelitian ini adalah terdapat perbedaan yang signifikan pada penyesuaian sosial anak asuh sebelum dan setelah mengikuti kegiatan pendekatan REBT Setting Group. Berdasarkan hasil pengujian tersebut diperoleh hasil perhitungan seperti yang terlihat pada tabel berikut.

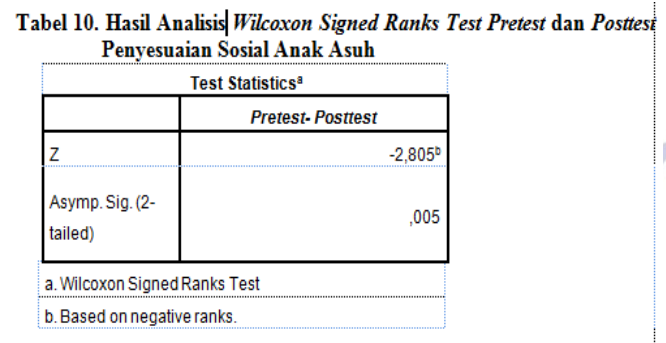

Berdasarkan Tabel 10 dapat dilihat bahwa angka probabilitas Asymp. Sig penyesuaian sosial pada kelompok kontrol sebesar 0,005 atau probabilitas dibawah Alpha $(0,005<0,05)$. Dari hasil tersebut diketahui bahwa terdapat perbedaan penyesuaian sosial anak asuh sebelum dan setelah mengikuti kegiatan pendekatan REBT Setting Group.

\section{PEMBAHASAN}

Hasil penelitian ini menunjukkan bahwa terdapat perbedaan yang signifikan pada skor rata-rata antara kondisi penyesuaian sosial anak asuh sebelum dan setelah mengikuti kegiatan pendekatan REBT Setting Group. Hasil pretest menunjukkan bahwa rata-rata anak asuh sulit melakukan penyesuaian sosial di panti asuhan, hal ini dibuktikan dengan rata-rata skor pretest sebesar 106 yang berada pada kategori kurang baik (maladjustment) sebelum mengikuti kegiatan pendekatan REBT Setting Group. Setelah mengikuti kegiatan pendekatan REBT Setting Group terjadi perubahan pada diri anak asuh yang akhirnya sudah mulai mampu menyesuaikan diri di lingkungan panti, hal ini dibuktikan dengan rata-rata skor posttest sebesar 160.8 yang berada pada kategori baik (well adjusted). Hal ini berarti REBT berhasil meningkatkan penyesuaian sosial di lingkungan panti dengan dibantu mengubah persepsi dan penghayatan melalui materi yang didiskusikan pada kegiatan kelompok.

Pemberian pendekatan REBT Setting Group dilakukan sebanyak 6 kali pertemuan, dimana setiap pertemuan diberikan materi-materi, teknik-teknik yang ada pada penerapan REBT Setting Group, serta diberikan model $A$ $B-C-D-E$ untuk membantu anggota kelompok menyadari pemikiran-pemikiran irasional yang menghambat kemampuan penyesuaian sosial anggota kelompok di lingkungan panti. Adapun materinya adalah: (1) sifat terbuka, (2) komunikasi antar pribadi, (3) tanggung jawab, dan (4) manajemen diri.

Schneiders (dalam Ghufron dan Rinaswita, 2010) berpendapat bahwa orang dikatakan kurang mampu menyesuaikan diri di lingkungan sosial atau penyesuaian yang rendah, apabila kesedihan, kekecewaan atau keputus asaan itu berkembang dan mempengaruhi fungsi fisiologis dan psikologisnya. Individu menjadi tidak mampu menggunakan pikiran dan sikap dengan baik sehingga tidak mampu mengatasi tekanan-tekanan yang muncul dengan jalan yang baik. Kegagalan individu dalam penyesuaian sosial dapat menyebabkan antara lain: ketegangan emosional yang berlebihan, mekanisme pertahanan diri yang salah, frustasi pribadi, memiliki pertimbangan irasional dalam pengarahan diri, gagal belajar pengalaman, bersikap tidak realistis, dan tidak objektif.

Terjadinya peningkatan pada masing-masing responden karena pada saat pelaksanaan pendekatan REBT Setting Group anggota kelompok diberikan model $A B C D E$ dimana anggota kelompok dilibatkan secara aktif dalam kelompok. Pada model $A B C D E$ yang diberikan, anggota kelompok mengemukakan pengalamanpengalaman yang menyebabkan pemikiran irasional yang menghambat penyesuaian sosial, selanjutnya pemimpin kelompok akan membantu disputing pemikiran irasional dengan memberikan pertanyaan-pertanyaan yang menentang pemikirannya sehingga dengan sendirinya anggota kelompok memahami dan menemukan pemikiran baru yang rasional.

Froggat (2003:17-21) menjelaskan "Sistem keyakinan merupakan faktor kunci dalam menentukan bagaimana perasaan dan perilaku individu bereaksi terhadap berbagai peristiwa dan keadaan". Dengan demikian, segala tindakan berawal dari suatu pemikiran yang membawa individu kepada arah perilaku dan perasaan dari apa yang dipikirkan. Ketidakmampuan menyesuaikan diri di lingkungan sosial berawal dari pemikiran irasional yang menganggap bahwa semua orang akan diterima di lingkungan sosial dan keharusan menjadi sempurna di mata orang lain. Pemikiran yang seharusnya adalah apabila tidak mampu mendapatkan situasi yang diinginkan, maka itu bukanlah sesuatu yang buruk.

Latipun (2008) menjelaskan klien yang cocok untuk REBT adalah klien yang mengalami kecemasan dengan tingkat moderat (sedang) gangguan neurotik, gangguan karakter, gangguan makan, dan ketidak mampuan dalam hubungn interpersonal. Berdasarkan hal tersebut maka sesuai dengan tujuan dari penggunaan pendekatan $R E B T$ yaitu untuk mengatasi penyesuaian sosial yang rendah. 
REBT memandang manusia memiliki potensi berpikir baik secara rasional maupun irasional dan hal yang menghambat kegiatan seseorang untuk menjadi lebih efektif adalah pemikiran irasional, pemikiran irasional, berarti pikiran, emosi, atau perilaku apapun yang menyebabkan berbagai konsekuensi yang merusak diri sendiri yang secara signifikan, dan menganggu kelangsungan hidup serta kebahagiaan individu itu sendiri (Ellis, 2007).

Kegiatan eksperimen dilakukan dengan melaksanakan pendekatan REBT Setting Group dengan model ABCDE dan teknik kognitif, teknik emotif, dan behavior untuk meningkatkan penyesuaian sosial anak asuh. Berdasarkan pelaksanaan kegiatan terungkap bahwa adanya pemikiran irasional yang dimiliki angota kelompok, dalam REBT salah satu pemikiran irasional adalah pandangan bahwa karena segala sesuatu kejadian sangat kuat pengaruhnya terhadap kehidupan, hal itu akan mempengaruhi dalam jangka waktu yang tidak terbatas. Seharusnya pandangan itu adalah diri sendiri dapat belajar dari pengalaman masa lalu, tetapi tidak terlalu mengikuti atau berprasangka terhadap pengalaman-pengalaman masa lalu itu.

Pernyataan tersebut banyak dikemukakan oleh anggota kelompok, seperti tidak bisa mempercayai orang lain dalam hal apapun, sehingga apabila mereka menemui kondisi tersulit di panti asuhan, mereka lebih memilih diam dan tertutup, bahkan menyalahkan kondisi mereka tinggal di panti. Setelah mengikuti kegiatan pendekatan $R E B T$ perubahan anak asuh mulai terlihat secara bertahap walaupun tidak terlalu banyak yang aktif pada setiap tahapnya, akan tetapi selama kegiatan anak asuh berani mengemukakan pendapatnya tentang permasalahan yang dirasakan sesuai dengan topik yang dibahas. REBT secara khusus dapat diterapkan untuk terapi kelompok dan kerja kelompok memberi banyak kesempatan mencapai kesepakatan mengenai pekerjaan rumah, untuk menantang pemikiran diri sendiri, dan untuk belajar dari pengalaman orang lain, dan serta saling berinteraksi antar sesama anggota (Ellis dalam Corey, 2012).

\section{SIMPULAN DAN SARAN}

Berdasarkan hasil penelitian yang diperoleh, dan setelah melakukan analisis statistik serta uji hipotesis, maka dapat disimpulkan secara umum bahwa pendekatan REBT dapat meningkatkan penyesuaian sosial anak asuh di panti asuhan, secara khusus temuan penelitian ini sebagai berikut.

1. Terdapat perbedaan yang signifikan pada skor rata-rata penyesuaian sosial anak asuh sebelum dan setelah mengikuti kegiatan pendekatan REBT Setting Group, dimana skor rata-rata posttest lebih tinggi daripada skor rata-rata pretest.
2. Pendekatan REBT Setting Group efektif dalam meningkatkan penyesuaian sosial anak asuh di panti asuhan. Pendekatan REBT Setting Group telah teruji keefektifannya untuk meningkatkan penyesuaian sosial yang rendah yang disebabkan oleh pemikiran irasional. Sehingga pada kegiatan pelaksanaan REBT Setting Group, konselor mengaktifkan anggota kelompok untuk merasionalkan pemikiran dan tingkah laku.

Berdasarkan kesimpulan yang telah dikemukakan, ada beberapa saran yang dapat diajukan sebagai tindak lanjut penelitian ini. Beberapa saran yang dapat diajukan adalah sebagai berikut.

1. Bagi Anak Asuh

Hasil penelitian menunjukkan bahwa pendekatan REBT Setting Group efektif dalam meningkatkan penyesuaian sosial. Oleh karena itu, diharapkan bagi anak asuh sebaiknya mengikuti kegiatan konseling di sekolah guna meningkatkan penyesuaian sosial, menghilangkan pemikiran irasional yang menghambat perkembangan kemampuan penyesuaian sosial, dan mengikuti kegiatan panti yang berkaitan dengan peningkatan penyesuaian sosial secara aktif.

2. Bagi Pengasuh dan Pengurus

Berdasarkan hasil penelitian, disarankan kepada pengasuh untuk memahami bahwa anak asuh yang berusia remaja mestinya sudah mampu menyesuaikan diri di lingkungan sosial. Oleh karena itu, pengurus dan pengasuh dapat memberikan program kegiatan berupa kerjasama dengan konselor untuk memberikan kegiatan pendekatan $R E B T$ guna membantu menghilangkan pemikiran irasional yang menghambat kemampuan penyesuaian sosial anak asuh.

3. Bagi Peneliti Selanjutnya

Disarankan kepada peneliti selanjutnya untuk dapat mengembangkan penelitian ini dengan menggunakan pendekatan REBT dengan setting personal, karena ditemukan di lapangan, bahwa anak asuh lebih terbuka menceritakan permasalahannya dalam keadaan face to face. Selanjutnya peneliti juga dapat menggunakan teknik yang berbeda, dan juga bisa dengan layanan yang berbeda, sehingga memperoleh ilmu baru dari hasil penelitian tersebut dan penyesuaian sosial pada remaja dapat meningkat.

4. Bagi Dinas Sosial

Sebagai bahan masukan untuk memberikan tenaga Konselor di panti asuhan agar dapat membantu anak asuh dalam kehidupan di panti asuhan. Serta memperhatikan program-program panti yang berkaitan dengan pengembangan kehidupan sosial. 
7 | Efektivitas Pendekatan Rational Emotive Behavior Therapy (REBT) dalam Meningkatkan Penyesuaian Sosial Anak Asuh di Panti Asuhan Wira Lisna Padang

\section{DAFTAR PUSTAKA}

Ali, M., dan Asrori, M. 2004. Psikologi Remaja Perkembangan Peserta Didik. Jakarta: Bumi Aksara.

Corey, G. 2012. Theory \& Practice of Group Counseling (Eight Edition). Canada: Cenge Learning.

Ellis, A., dan Dryden, W. 2003. Albert Ellis Live!. London: SAGE Publications.

Froggat, W. 2003. Free From Stress. Jakarta: Buana Ilmu Populer.

Ghufron, M. N., dan Rinaswita, R. S. 2010. Teori-teori Psikologi. Yogyakarta: Ar-ruzz Media.

Hartati, L., dan Respati, W.S. 2012. "Kompetensi Interpersonal pada Remaja yang Tinggal di Panti Asuhan Asrama dan yang Tinggal di Panti Asuhan Cottage". Jurnal Psikologi, (Online), Vol. 10, No. 2, (www. e-jurnal.com/ 2013/09/kompetensiinterpersonal-pada-remaja.html? $\mathrm{m}=1$, diakses 12 Mei 2015).

Latipun. 2011. Psikologi Konseling. Malang: UMM Press.

Prayitno. 1995. Layanan Bimbingan dan Konseling Kelompok: Dasar dan profil. Jakarta: Ghalia Indonesia.

Putra, R.S., dan Rahmah, E. 2013. "Pemanfaatan Perpustakaan sebagai Sumber Belajar di Panti asuhan Wira Lisna Mata Air Padang”. Jurnal Ilmu Informasi Perpustakaan dan Kearsipan, (Online), Vol. 2. No. 1, (http:// journal. fbs. unp . ac. id/ 2013/ 9/ pemanfaatan - perpustakaan - sebagai sumber. Html ? $\mathrm{m}=1$, diakses 5 Mei 2015).

Schneiders, A. A. 1964. Personal Adjustment and Mental Health. New York: Library of Congress Catalog.

Surya, M. 2003. Teori-teori Konseling. Bandung: Pustaka Bani Quraisy.

Yusuf, S. 2006. Psikologi Perkembangan Anak dan Remaja. Bandung: Remaja Rosdakarya.

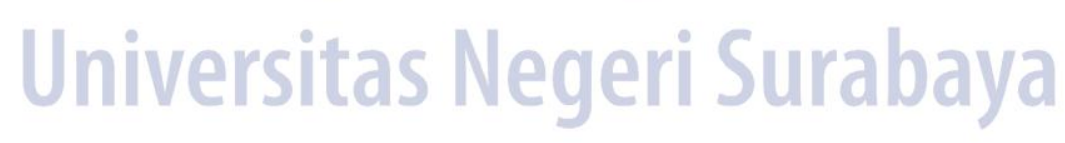

